\title{
INTEGRACJA RACHUNKOWOŚCI FINANSOWEJ I ZARZĄDCZEJ, Z PERSPEKTYWY RAPORTOWANIA INFORMACJI O SEGMENTACH DZIALALNOŚCI NA PRZYKLADZIE BADANEGO PRZEDSIĘBIORSTWA
}

\section{Wstęp}

Rachunkowość na przestrzeni ostatnich kilkudziesięciu lat zmieniała się. Globalizacja przyczyniła się do tych zmian, po pierwsze - spowodowała harmonizację i standaryzację sprawozdawczości finansowej, po drugie - wymusiła integrację rachunkowości finansowej i zarządczej. Są to dwa główne trendy rozwoju rachunkowości. W ich ramach można wskazać wiele nowych aspektów, wyzwań stojących przed rachunkowością XXI w. To wiek dominacji wartości przedsiębiorstwa jako miernika jego dokonań ${ }^{1}$. Podstawowym wyzwaniem współczesnej rachunkowości jest opracowanie takiego modelu ujawnień informacji prezentowanych $\mathrm{w}$ sprawozdaniach finansowych, który umożliwiłby realizację stawianych przed nią celów. Problem prezentacji i ujawnień informacji w sprawozdaniach finansowych został podjęty w 2011 r. także przez IASB ${ }^{2}$, która zapoczątkowała publiczną dyskusję na ten temat ${ }^{3}$. W ramach prezentacji informacji w sprawozdaniach finansowych coraz szerzej ujawnia się informacje pochodzące $\mathrm{z}$ rachunkowości zarządczej. W tym kontekście pojawił się problem integracji rachunkowości finansowej ${ }^{4}$ i zarządczej $^{5} \mathrm{w}$ jeden spójny system

\footnotetext{
* Doktor, Katedra Rachunkowości, Wydział Zarządzania UŁ.

${ }^{1}$ Tak jak napisała I. Sobańska: „U podstaw dokonujących się zmian w procesach zarządzania i obu obszarach rachunkowości leży zastosowanie amerykańskiej teorii wartości kapitału dla akcjonariuszy. [...] Zorientowanie procesów zarządzania i obu obszarów rachunkowości na tworzenie i pomiar wartości przedsiębiorstwa w długim okresie oznacza kres stosowania tradycyjnych rozwiązań rachunkowości". I Sobańska, Nowa orientacja systemu rachunkowości w praktyce polskiej w kontekście wdrażania MSR/MSSF, [w:] T. Cebrowska, A. Kowalik, R. Stępień (red.), Rachunkowość wczoraj, dziś i jutro, SKwP, Warszawa 2007, s. 277-278.

${ }^{2}$ Rada Międzynarodowych Standardów Rachunkowości.

${ }^{3}$ I. Mackintosh, The disclosure problem: setting the scene Discussion Forum - Disclosures in Financial Reporting, www.ifrs.org (dostęp 07.03.2013).

${ }^{4} \mathrm{Na}$ potrzeby niniejszego artykułu pominięto zagadnienia rachunkowości środowiskowej czy podatkowej.

${ }^{5} \mathrm{~W}$ literaturze przedmiotu toczy się spór o to, czy rachunkowość zarządcza jest tożsama z pojęciem controllingu. W niniejszym artykule przyjęto założenie, że pojęcia te są tożsame i mogą być traktowane zamiennie.
} 
rachunkowości. I. Sobańska wskazała na ten problem już w 2002 r. ${ }^{6}$ Od 2004 r., wraz z wprowadzaniem regulacji MSR/MSSF do rachunkowości finansowej, występuje wręcz konieczność łączenia tych podsystemów rachunkowości, tj. finansowej i zarządczej, w jeden zintegrowany system. Przez wiele dziesięcioleci podział na rachunkowość zarządczą i finansową był spowodowany zapotrzebowaniem praktyki. W ostatnich latach można zaobserwować tendencję integracji rachunkowości finansowej i zarządczej ${ }^{7}$ na rzecz oddzielania się rachunkowości podatkowej ${ }^{8}$, zmierzającej do wyliczenia obciążeń budżetowych. Rachunkowość może sprawnie funkcjonować w jednostce tylko wtedy, gdy sprawnie działają jej kluczowe elementy - rachunkowość finansowa i zarządcza. Elementy te oprócz celów ogólnych stawianych przed rachunkowością realizują specyficzne cele cząstkowe kierowane od ich adresem.

Celem artykułu jest przedstawienie problemu integracji rachunkowości finansowej i zarządczej. W artykule wykorzystano studia literaturowe - polskiej i zagranicznej literatury przedmiotu, wykorzystano także badania empiryczne. Badania empiryczne zostały przeprowadzone w spółce kapitałowej i obejmowały okres od 2001 do 2009 r. Głównym celem badań była analiza procesu integracji rachunkowości finansowej i zarządczej.

\section{Rachunkowość finansowa, a rachunkowość zarządeza}

Rachunkowość finansowa generuje informacje finansowe ex-post i służy przede wszystkim odbiorcom zewnętrznym, jest także ściśle regulowana przepisami prawnymi obowiązującymi $\mathrm{w}$ danym kraju (w Polsce są to ustawa o rachunkowości, przepisy Komisji Papierów Wartościowych, Ministra Finansów, Krajowe Standardy Rachunkowości, Dyrektywy Komisji Europejskiej, Międzynarodowe Standardy Rachunkowości i inne $)^{9}$. Przepisy te wymagają, by generowane $\mathrm{w}$ ramach systemu rachunkowości finansowej informacje spełniały cechy

${ }^{6}$ I. Sobańska, Potrzeba integracji rachunkowości zarządczej i rachunkowości finansowej $w$ praktyce jako efekt zmian zasad sporzadzania sprawozdań finansowych w Polsce i krajach Unii Europejskiej, „Zeszyty Teoretyczne Rachunkowości” 2004, t. 18(74), s. 107.

${ }^{7}$ E. Nowak (red.), Rachunkowość a controlling, Prace naukowe Akademii Ekonomicznej im. O. Langego we Wrocławiu, Wydawnictwo AE we Wrocławiu, Wrocław 2005, s. 11.

${ }^{8}$ Rachunkowość podatkowa (bazuje na finansowej, która jest punktem wyjścia) wymaga niejednokrotnie prowadzenia dodatkowej ewidencji np. amortyzacji dla celów podatkowych. Różnice przejściowe wynikające $\mathrm{z}$ odmiennego podejścia do ustalania wyniku finansowego bilansowego i podatkowego kumulują się w kalkulacji podatku odroczonego i jako takie mają wpływ na wynik finansowy netto. Oczywiście oprócz różnic przejściowych występują też różnice trwałe.

${ }^{9}$ A.A. Jaruga, W.A. Nowak, A. Szychta, Rachunkowość zarządcza. Koncepcje i zastosowania, Społeczna Wyższa Szkoła Przedsiębiorczości i Zarządzania w Łodzi, Łódź 2001, s. 37. 
jakościowe (za A.A. Jarugą) ${ }^{10}$ : dokładność, porównywalność, ciągłość, sprawdzalność itp. gwarantujące informacji wiarygodność i istotność.

Rachunkowość zarządcza ${ }^{11}$ nie podlega regulacjom prawnym, a jedynie wewnętrznym, jej kształt zależy od potrzeb kadry zarządzającej przedsiębiorstwem. Nie ulega jednak wątpliwości, że informacje zawarte w raportach zarządczych powinny spełniać te same cechy jakościowe jak te, które są zawarte w sprawozdaniach finansowych. Jedynie ich agregacja, sposób przedstawienia czy okresy raportowania różnią się w zależności od wytycznych wewnętrznych w jednostce. W literaturze przeważa pogląd, że współcześnie rachunkowość zarządcza zmienia się pod wpływem: globalizacji rynków, rozwoju zarządzania strategicznego, rozwoju technologii i tworzenia nowych elastycznych struktur organizacyjnych $^{12}$. Podstawowym jej celem jest dostarczanie informacji użytecznych kierownikom różnych szczebli dla zarządzania przedsiębiorstwem; „rozumiana jest, jako system rachunków służący odkrywaniu efektywnych obszarów działania podmiotu" ${ }^{\text {13 }}$. Mimo zmian zachodzących w podsystemie rachunkowości zarządczej nadal w jej centrum znajduje się rachunek kosztów i wyników.

Jak pisze A. Szychta, ,uzasadnione jest stwierdzenie, że procesy globalizacji $[\ldots]$ oraz $[\ldots]$ wprowadzanie w poszczególnych krajach jednolitych zasad

${ }^{10}$ Ibidem, s. 38.

${ }^{11}$ Międzynarodowa Federacja Księgowych (International Federation of Accountants IFAC) definiuje rachunkowość zarządczą jako: ,proces identyfikacji, pomiaru, analizy, przygotowania i komunikowania informacji (finansowych i operacyjnych) stosowanych przez kierowników do planowania, oceny i kontroli w ramach organizacji oraz do zapewnienia efektywnego wykorzystania zasobów", za: ibidem, s. 23. Najbardziej całościową i wyczerpującą definicję rachunkowości zarządczej podaje CIMA (The Chartered Institute of Management Accountants): „Rachunkowość zarządcza jest wdrożeniem zasad rachunkowości i zarządzania finansami w celu kreowania, ochrony, zabezpieczenia i wzrostu wartości dla akcjonariuszy (właścicieli, inwestorów) dochodowych (profit) i nie-dochodowych jednostek w publicznym i prywatnym sektorze. Rachunkowość zarządcza jest integralną częścią zarządzania. To wymaga identyfikacji, generowania, prezentacji, interpretacji i wykorzystania istotnych informacji w celu: a) komunikowania decyzji strategicznych i formułowania strategii jednostki, b) planowania długo-, średnioi krótkookresowego, c) określania struktury kapitału i pozyskiwania ustalonej struktury, d) projektowania strategii przynoszących korzyści dla zarządzających i właścicieli, e) komunikowania decyzji operacyjnych, f) kontrolowania procesów (zdarzeń i operacji) w celu upewnienia się, że zasoby wykorzystywane są efektywnie, g) pomiaru i raportowania finansowego i nie-finansowego wyniku do kierownictwa $\mathrm{i}$ innych np. właścicieli, h) zabezpieczania wartości niematerialnych i materialnych, i) wdrażania ładu korporacyjnego, zarządzania ryzykiem i procedur kontroli wewnętrznej". Improving decision making in organisations, The opportunity to transform finance, September 2007, Appendix 1, www2.cimaglobal.com (dostęp 20.08.2008), s. 53, zgodnie z CIMA Official Terminology, 2005 Edition.

${ }^{12}$ I. Sobańska (red.), Rachunek kosztów i rachunkowość zarządcza, C.H. Beck, Warszawa 2003, s. 33.

${ }^{13}$ Ibidem, s. 33. 
rachunkowości finansowej ${ }^{14}[\ldots]$ przyczyniają się do stopniowej harmonizacji systemów rachunkowości zarządczej przedsiębiorstw, których działalność przekracza granice państw i kontynentów. Mimo, że MSR i Dyrektywy UE o rachunkowości nie odnoszą się bezpośrednio do rachunkowości zarządczej, to ich wdrażanie $\mathrm{w}$ przedsiębiorstwie tworzy podstawę do przemyślenia i weryfikacji [...] rozwiązań w zakresie pomiaru i ewidencji zdarzeń oraz sprawozdawczości zewnętrznej i wewnętrznej”" „prawidłowe wdrożenia MSR [MSSF] wymaga informacji z obu obszarów rachunkowości $[\ldots]$ tzn. rachunkowości finansowej i [...] zarządczej. Potrzeba integracji obu obszarów rachunkowości stała się koniecznością"16. Zmiany rzeczywistości gospodarczej wiążą się także z przekształcaniem funkcji rachunkowości zarządczej, jednak nadal jej nadrzędnym zadaniem pozostaje zapewnienie „,warunków do długotrwałej egzystencji przedsiębiorstwa i zagwarantowanie stabilności zatrudnienia, którą osiąga się przez tworzenie odpowiednich struktur wewnętrznych w przedsiębiorstwie i zintegrowanie celów”, którymi są wzrost, rozwój, zysk, ,z systemem planowania oraz systemem informacyjnym"

Jako podsumowanie rozważań dotyczących celów, zadań i funkcji rachunkowości może posłużyć klasyczne porównanie głównych charakterystyk rachunkowości finansowej i zarządczej (por. tabela 1).

Tabela 1. Charakterystyka rachunkowości finansowej i zarządczej

\begin{tabular}{|l|l|l|}
\hline \multicolumn{1}{|c|}{ Kryterium } & \multicolumn{1}{|c|}{ Rachunkowość finansowa } & \multicolumn{1}{|c|}{ Rachunkowość zarządcza } \\
\hline \multicolumn{1}{|c|}{ Obszar wiedzy } & \multicolumn{1}{|c|}{\begin{tabular}{l}
\multicolumn{1}{|c|}{ Finanse przedsiębiorstw } \\
Analiza finansowa \\
Sprawozdawczość finansowa
\end{tabular}} & $\begin{array}{l}\text { Mikroekonomia } \\
\text { Teoria zachowań } \\
\text { Zarządzanie i marketing } \\
\text { Badania operacyjne }\end{array}$ \\
\hline Cel & $\begin{array}{l}\text { Informacje finansowe o rezulta- } \\
\text { tach działalności zgodnie z zasa- } \\
\text { dą true and fair view }\end{array}$ & $\begin{array}{l}\text { Tworzenie informacji dla decyzji } \\
\text { i kontroli ich realizacji (informacje } \\
\text { finansowe i niefinansowe) }\end{array}$ \\
\hline $\begin{array}{l}\text { Obiekt obserwacji } \\
\text { (zakres sporządza- } \\
\text { nych sprawozdań } \\
\text { i raportów) }\end{array}$ & $\begin{array}{l}\text { Przedsiębiorstwo: } \\
\text { - jednostkowe; } \\
\text { - grupowe. }\end{array}$ & $\begin{array}{l}\text { Jednostki specyficzne dla przedsię- } \\
\text { biorstwa (np. ośrodki odpowiedzial- } \\
\text { ności, procesy, produkty itp.) }\end{array}$ \\
\hline Użytkownicy & $\begin{array}{l}\text { Zewnętrzni: inwestorzy, kredyto- } \\
\text { dawcy, analitycy, instytucje } \\
\text { rządowe itp. }\end{array}$ & $\begin{array}{l}\text { Wewnętrzni: kierownicy różnych } \\
\text { szczebli, pracownicy }\end{array}$ \\
\hline
\end{tabular}

${ }^{14}$ Określonych w dyrektywach UE oraz MSR/MSSF.

15 A. Szychta, Etapy ewolucji i kierunki integracji metod rachunkowości zarzaddzej, Wydawnictwo UŁ, Łódź 2008, s. 210.

${ }^{16}$ I. Sobańska, Potrzeba integracji..., s.101.

${ }^{17}$ M. Sierpińska, B. Niedbała, Controlling operacyjny w przedsiębiorstwie, Centra odpowiedzialności w teorii i praktyce, Wydawnictwo Naukowe PWN, Warszawa 2004, s. 15, www.ibuk.pl (dostęp 20.08.2008). 


\begin{tabular}{|c|c|c|}
\hline 1 & 2 & 3 \\
\hline Wymagania prawne & $\begin{array}{l}\text { Obligatoryjne. Regulacje prawne } \\
\text { m.in.: ustawa o rachunkowości, } \\
\text { kodeks handlowy, prawo podat- } \\
\text { kowe, akty prawne ministra } \\
\text { finansów, międzynarodowe } \\
\text { standardy rachunkowości itp. }\end{array}$ & Brak regulacji prawnych \\
\hline Nośniki informacji & $\begin{array}{l}\text { Sprawozdania finansowe, okre- } \\
\text { sowe według krajowych lub } \\
\text { międzynarodowych wymagań } \\
\text { prawnych }\end{array}$ & $\begin{array}{l}\text { Raporty wewnętrzne według zapo- } \\
\text { trzebowania użytkowników (standar- } \\
\text { dowe i specjalne) }\end{array}$ \\
\hline Dokładność & $\begin{array}{l}\text { Zachowuje wymagane cechy } \\
\text { dokładności, prawidłowości, } \\
\text { ciągłości, sprawdzalności, istot- } \\
\text { ności itp. zapewniające wysoką } \\
\text { jakość informacji tj. wiarygod- } \\
\text { ność i rzetelność danych }\end{array}$ & $\begin{array}{l}\text { Zorientowana jest na istotność, } \\
\text { szybkość i koszt informacji. „Różne } \\
\text { koszty dla różnych celów” }\end{array}$ \\
\hline Wymiar czasowy & $\begin{array}{l}\text { Oparta na przeszłości - dostarcza } \\
\text { informacji historycznych. Jeden } \\
\text { okres sprawozdawczy, plus dane } \\
\text { porównawcze z poprzedniego } \\
\text { okresu }\end{array}$ & $\begin{array}{l}\text { Informacje przeszłe związane są } \\
\text { z podejmowaniem decyzji i projek- } \\
\text { towaniem przyszłości. Akcentuje } \\
\text { przyszłość, wielookresowość }\end{array}$ \\
\hline Kryterium & Rachunkowość finansowa & Rachunkowość zarządcza \\
\hline Częstotliwość & $\begin{array}{l}\text { Ścisła periodyzacja: rok obroto- } \\
\text { wy, kwartał, półrocze itp. }\end{array}$ & $\begin{array}{l}\text { Cykl sprawozdawczy dostosowany } \\
\text { jest do konkretnej sytuacji i we- } \\
\text { wnętrznych wymagań kierownictwa }\end{array}$ \\
\hline $\begin{array}{l}\text { Rodzaj danych } \\
\text { objętych pomiarem }\end{array}$ & $\begin{array}{l}\text { Pomiar wartościowy danych } \\
\text { historycznych }\end{array}$ & $\begin{array}{l}\text { Pomiar danych finansowych i nie- } \\
\text { finansowych, ilościowych i jako- } \\
\text { ściowych }\end{array}$ \\
\hline Rodzaj kontroli & $\begin{array}{l}\text { Rewizja księgowa i kontrola } \\
\text { finansowa zewnętrzna (audyt) } \\
\text { i wewnętrzna }\end{array}$ & $\begin{array}{l}\text { Sama stanowi organ kierowniczej } \\
\text { kontroli efektywności i skuteczności } \\
\text { stosując kryteria i mierniki motywu- } \\
\text { jące }\end{array}$ \\
\hline Metody, zasady & Metody i zasady rachunkowości & $\begin{array}{l}\text { Systemy rachunku kosztów i wyni- } \\
\text { ków. Metody optymalizacji decyzji. } \\
\text { Zasady motywowania }\end{array}$ \\
\hline Elementy wspólne & \multicolumn{2}{|l|}{ Plan kont, polityka rachunkowości } \\
\hline
\end{tabular}

Źródło: I. Sobańska (red.), Rachunek kosztów i rachunkowość zarządcza, Wydawnictwo C.H. Beck, Warszawa, 2003, s. 34; A. Jaruga, Rola rachunkowości zarządczej, [w:] A.A. Jaruga, W.A Nowak., A. Szychta, Rachunkowość zarządcza. Koncepcje $i$ zastosowania, Społeczna Wyższa Szkoła Przedsiębiorczości i Zarządzania w Łodzi, Łódź 1999, s. 38-39; W. Brzezin, Ogólna teoria rachunkowości, Wydawnictwo Politechniki Częstochowskiej, Częstochowa 1998, s. 32-33, za: S. Sojak, Rachunkowość zarządcza, Wydawnictwo „Dom Organizatora”, Toruń 2003, s. 22; T. Kiziukiewicz (red.), Zarządcze aspekty rachunkowości, PWE, Warszawa 2003, s. 268. 
W rachunkowości finansowej i zarządczej występują elementy wspólne, natomiast różnią się cele i metody działania. W centrum zainteresowania rachunkowości finansowej są metody i zasady ujmowania, wyceny i ujawniania regulowane prawnie, rachunkowość ta ma określoną strukturę, natomiast, jeżeli chodzi o rachunkowość zarządczą jest ona elastycznie dostosowana do potrzeb danej jednostki, może posługiwać się różnymi metodami i korzystać z wiedzy innych dziedzin naukowych. Globalizacja zmieniła charakterystyki rachunkowości finansowej oraz zarządczej. Rachunkowość finansowa - poprzez sprawozdania finansowe nie informuje już tylko o przeszłości, przestała mierzyć tylko dane historyczne i wprowadziła pomiar przyszłych dokonań - korzystając z narzędzi wypracowanych przez rachunkowość zarządczą. Sprawozdania finansowe, obok typowych elementów takich jak bilans i rachunek zysków i strat, obejmuje także wiele innych sprawozdań ${ }^{18}$ i raportów finansowych, ale również dane niefinansowe. Cele i zadania rachunkowości kształtowały się nie tylko przez praktykę gospodarczą, bardzo istotny wpływ mają w tym względzie różne koncepcje teoretyczne. Integracja zasad pomiaru, wyceny aktywów i pasywów była pierwszym etapem zbliżania rachunkowości finansowej i zarządczej, obecnie postępuje integracja na płaszczyźnie prezentacji sprawozdań finansowych. Cel nadrzędny integracji prezentacji sprawozdań to umożliwienie odbiorcom zewnętrznym spojrzenia na jednostkę od wewnątrz, co sprzyja zwiększaniu jakości informacji, a w tym jej użyteczności i zrozumiałości ${ }^{19}$.

W wyniku wprowadzania międzynarodowych standardów sprawozdawczości finansowej następuje integracja rachunkowości finansowej i zarządczej, przy czym to właśnie rachunkowość finansowa nabiera cech zarządczej. Informacje, które do tej pory służyły jednie decyzjom wewnętrznym i podlegały wymogom tajności, a ich ujawnianie było traktowane jako wykroczenie przeciwko przedsiębiorstwu, teraz w coraz szerszym zakresie ujawniane są dla odbiorców zewnętrznych.

Rachunkowość zarządcza przenika do rachunkowości finansowej w coraz szerszym zakresie, można zauważyć to w szczególności w następujących obszarach:

1) ewidencji i alokacji kosztów oraz przychodów;

2) metodach wyceny aktywów;

3) prezentacji sprawozdań finansowych.

${ }^{18} \mathrm{~Np}$. rachunkowość finansowa przyjmuje od rachunkowości zarządczej dane dotyczące jednostek wewnętrznych przedsiębiorstwa (segmentów działalności/operacyjnych) i ujawnia je w sprawozdaniu finansowym.

${ }^{19}$ Najlepszym przykładem takiego podejścia jest sprawozdawczość według segmentów operacyjnych, o ile w nadal obowiązującej regulacji IAS 14 można było nie bazować na rachunkowości zarządczej, podzielić niejako wtórnie sporządzone sprawozdanie na segmenty, to już IFRS 8 obowiązujący od 01.01.2009 wprowadza wymóg bazowania na raportach wewnętrznych. 
Przeniesienie szeregu rozwiązań stosowanych w rachunkowości zarządczej do rachunkowości finansowej ${ }^{20} \mathrm{i}$ jej głównego produktu, tj. sprawozdania finansowego, wymagane jest $\mathrm{w}$ ramach różnych międzynarodowych standardów MSR/MSSF, m.in. MSR 2 Zapasy, MSR 11 Umowy o usługę budowlaną, MSR 16 Rzeczowe aktywa trwałe, MSR 36 Utrata wartości aktywów, MSSF 5 aktywa przeznaczone do sprzedaży, MSSF 8 Segmenty operacyjne.

Jednym z przykładów są regulacje dotyczące segmentów działalności ${ }^{21}$ zawarte w MSSF 822 .

\section{Raportowanie informacji o segmentach działalności}

Koncepcja podziału przedsiębiorstwa na segmenty operacyjne wywodzi się z nauki i praktyki zarządzania przedsiębiorstwem w oparciu o jego zdecentralizowaną strukturę - wydzielone ośrodki odpowiedzialności ${ }^{23}$.

$\mathrm{Na}$ potrzeby rachunkowości zarządczej stworzono kategorię ośrodka odpowiedzialności, który można zdefiniować jako „względnie wyodrębnioną i zorganizowaną jednostkę wewnętrzną, stanowiącą część organizacji przedsiębiorstwa. Na czele ośrodka stoi kierownik, który ponosi odpowiedzialność za

${ }^{20}$ Por. I. Sobańska, Nowa orientacja..., s. 288-292.

${ }^{21}$ „Segment operacyjny jest częścią składową jednostki: a) która angażuje się w działalność gospodarczą, w związku z którą może uzyskiwać przychody i ponosić koszty (w tym przychody i koszty związane $\mathrm{z}$ transakcjami z innymi częściami składowymi tej samej jednostki); b) której wyniki działalności są regularnie przeglądane przez główny organ odpowiedzialny za podejmowanie decyzji operacyjnych $w$ jednostce oraz wykorzystujący te wyniki przy podejmowaniu decyzji o zasobach alokowanych do segmentu i przy ocenie wyników działalności segmentu; oraz c) w przypadku której dostępne są oddzielne informacje finansowe”. Opracowanie na podstawie MSSF 8 Segmenty operacyjne Tekst jednolity z 27.03.2010 r. Rozporządzenia Komisji (WE) nr 1126/2008 z dnia 03.11.2008 r. przyjmujące określone międzynarodowe standardy rachunkowości zgodnie z rozporządzeniem (WE) nr 1606/2002 Parlamentu Europejskiego i Rady, http:// eur-lex.europa.eu (dostęp 27.04.2011).

${ }^{22}$ Pierwotnie MSR 14, obecnie MSSF 8.

${ }^{23}$ Zgodnie z literaturą z zakresu zarządzania strukturę organizacyjną można podzielić na dwie główne grupy zdecentralizowaną i scentralizowaną. Simon (1954) podaje następującą definicję, pozwalającą na odróżnienie scentralizowanej i zdecentralizowanej struktury: „struktura przedsiębiorstwa jest scentralizowana wtedy, gdy decyzje podejmowane są przez kierownictwo stosunkowo wysokiego szczebla w organizacji (top management), struktura jest zdecentralizowana wtedy, gdy władza i możliwość podejmowania ważnych decyzji jest przekazana na niższe szczeble organizacji w ręce kierownictwa operacyjnego". Mintzberg and Quinn (1996) definiują decentralizację, jako rozproszenie władzy do podejmowania decyzji. Definicje powyższe doskonale oddają ideę wydzielania ośrodków odpowiedzialności w przedsiębiorstwie - obowiązki, ale także władza i uprawnienia delegowane są na ręce kierownictwa niższego szczebla. Jednostka widziana jest bardziej jako suma wydzielonych jednostek organizacyjnych, niż jako całość. C. Drury, H. ELShishini, Research Report. Divisional Performance Measurement: An Examination of the Potential Explanatory Factors, 2005, s. 8, www2.cimaglobal.com (dostęp 20.08.2008). 
wykonanie zadań przypisanych ośrodkowi i jednocześnie ma do dyspozycji odpowiednie środki, umożliwiające zrealizowanie postawionych zadań"24. Natomiast definicja podana $\mathrm{w}$ badaniach firmowanych przez $\mathrm{CIMA}^{25}$ mówi, że część organizacji jest określanych jako wydzielony segment w ramach jednostki, który ma kierownika odpowiedzialnego za większość działań produkcyjnych i marketingowych segmentu oraz za finansowe rezultaty segmentu. Czasami kierownik segmentu jest odpowiedzialny także za działania inwestycyjne. Wydzielona część organizacji może być nazwana centrum inwestycji, centrum zysku, jednostką zależną, wydziałem, sektorem lub jednostką biznesową. W zależności od potrzeb jednostki ośrodki odpowiedzialności ${ }^{26}$ można wyodrębniać, posługując się różnorodnymi kryteriami ${ }^{27}$. Informatyzacja i zaawansowane technologie umożliwiają rozwój zarządzania poprzez ośrodki odpowie-

${ }^{24}$ E. Nowak, Zaawansowana rachunkowość zarządcza, PWE, Warszawa 2003, s. 188.

${ }^{25}$ C. Drury, H. EL-Shishini, Research Report..., s. 6, w brzmieniu oryginalnym: ,a division is defined as a segment within the organization where the divisional chief executive has responsibility for most of the production and marketing activities of the segment and is accountable for a profitability measure. Sometimes, the divisional chief executive has responsibility for the investment activities. The division may be known within the organization as a profit or investment centre, subsidiary, branch, sector or business unit".

${ }^{26}$ Należy podkreślić, że już na etapie wydzielania centrów odpowiedzialności trzeba wziąć pod uwagę ewentualny wzrost przedsiębiorstwa i zorganizować zdecentralizowaną strukturę w taki sposób, by można było bez problemu dodać kolejny ośrodek.

${ }^{27}$ Do najważniejszych zalicza się: kryterium organizacyjne (ośrodki odpowiadają jednostkom wyodrębnionym w strukturze przedsiębiorstwa); kryterium funkcjonalne (według tych samych funkcji spełnianych w jednostce); kryterium produktowe (według rodzajów działalności, rodzajów produktu); kryterium przestrzenne (według obszarów geograficznych, lokalizacji zakładów przedsiębiorstwa); kryterium procesowe (podział według procesów biznesowych i wyodrębnionych w ich ramach działań); kryterium dystrybucyjne (np. według asortymentu sprzedawanych wyrobów, obszarów sprzedaży, grup klientów, kanałów dystrybucji) - ten podział jest najbardziej zbieżny z segmentacja marketingową; kryterium zadaniowe (według zadań produkcyjnych) E. Nowak, Zaawansowana rachunkowość..., s. 19. „kryteria wydzielenia miejsc powstawania kosztów czy realizacji przychodów przyjmują orientację na obiekty, lub orientację funkcjonalną. Orientacja na obiekty oznacza wyodrębnienie centrów odpowiedzialności ze względu na obiekt, na którym skupione będą działania. Obiektem może być określony produkt, projekt, zlecenie, itp. stąd w przypadku centrów odpowiedzialności wydzielonych zgodnie z tym kryterium posiadają one charakter produktowy, projektowy, zleceniowy itp. Orientacja funkcjonalna polega na takim podziale przedsiębiorstwa na ośrodki odpowiedzialności, żeby w każdym ośrodku (tzw. ośrodku funkcjonalnym) zebrać działania i majątek decydujące o określonej funkcji przedsiębiorstwa, np. zaopatrzenia, produkcji, sprzedaży, obsługi administracyjnej. W praktyce bardzo często stosuje się zarówno podział według orientacji na obiekty, jak i orientacji funkcjonalnej. Takie podejście umożliwia właściwą metodologię kalkulacji kosztów w działalności podstawowej wraz z możliwością szczegółowego monitoringu komórek organizacyjnych wspierających sferę tejże działalności”. E. Ignaszewska, Jak wydzielić ośrodki odpowiedzialności - to nie takie proste jak sie nam wydawato, „Controlling i Rachunkowość Zarządcza” 2005, nr 8, www.budżetowanie.pl (dostęp 20.08.2008). 
dzialności ${ }^{28}$. Wydzielenie ich wymaga zmian w całym systemie rachunkowości w przedsiębiorstwie (plan kont, zasady rozliczeń wewnętrznych, tworzenia rachunku kosztów itp. $)^{29}$. Wydzielanie ośrodków odpowiedzialności jest bardzo popularne także ze względu na rozłożenie odpowiedzialności za wyniki przedsiębiorstwa jako całości na poszczególne komórki odpowiedzialne za zarządzanie $^{30}$.

Wyodrębnione centra odpowiedzialności staną się nimi wtedy, gdy przedsiębiorstwo $\mathrm{w}$ ślad za ich wydzieleniem przekaże kierownikom ośrodków odpowiednie kompetencje decyzyjne i odpowiedzialność za realizację celów wyznaczonych dla konkretnych centrów odpowiedzialności ${ }^{31}$.

Reasumując, wdrożenie ośrodków odpowiedzialności w systemie zarządzania przedsiębiorstwem daje konkretne korzyści, jednostka przechodzi od struktury centralnie zarządzanej do hierarchicznie zdecentralizowanej o określonych kanałach przepływu informacji i procedurach kontroli dokonań poszczególnych wydzielonych fragmentów organizacji. Poprzez wdrożenie narzędzi rachunkowości zarządczej dla oceny dokonań ośrodków odpowiedzialności można monitorować wszystkie ważne grupy kosztów i przychodów oraz szybko reagować na pojawiające się zakłócenia, łatwo można zidentyfikować produkty strategiczne oraz te, które są obciążeniem, co umożliwia weryfikację oferowanego asortymentu oraz maksymalizację i optymalizację zysku ${ }^{32}$.

$\mathrm{Na}$ tym tle powstała koncepcja ujawniania struktury wewnętrznej i poszczególnych obszarów działalności przedsiębiorstwa dla odbiorców zewnętrznych, użytkowników sprawozdania finansowego, zawarta w MSSF 8.

Sprawozdawczość według segmentów najlepiej odzwierciedla tendencję wzajemnego przenikania się rachunkowości zarządczej i finansowej we wszystkich płaszczyznach (tj. ewidencji, wyceny, prezentacji). Wymogi narzucone przez MSSF 8 zmuszają do ujawniania informacji dostępnych dotąd jedynie

${ }^{28}$ I odwrotnie - ograniczeniem dla wdrażania bardzo rozbudowanego podziału na ośrodki odpowiedzialności są ograniczenia stosowanego programu informatycznego.

${ }^{29}$ Williamson (1975) podkreśla znaczenie kontroli wewnętrznej w przedsiębiorstwach podzielonych (zdecentralizowanych) na ośrodki odpowiedzialności. Kontrola wewnętrzna posługuje się trzema głównymi narzędziami: kierowanie, przez wydzielone centrum, bodźcami motywującymi takimi jak warunki wynagrodzeń, premii i bonusów; wewnętrzny audit; centralizacja procesu lokowania nadwyżek finansowych (centralizacja zarządzania przepływami pieniężnymi). Williamson uważa, że najważniejsza jest kontrola przepływów pieniężnych. Twierdzi, że nadwyżki pieniężne wypracowane przez ośrodek odpowiedzialności (wydzieloną dywizję) powinny być zarządzane centralnie i alokowane z powrotem do ośrodków w oparciu o przewidywania dotyczące przyszłego, przewidywanego zapotrzebowania ośrodka. Za: C. Drury, H. EL-Shishini, Research Report..., s. 8.

${ }^{30}$ E. Ignaszewska, Jak wydzielić...

${ }^{31}$ Ibidem.

${ }^{32}$ Por. W. Kulpiński, Czy controlling jest potrzebny polskiej firmie?, www.controlling.info.pl (dostęp 20.08.2008). 
w raportach tworzonych na wewnętrzne potrzeby przez rachunkowość zarządczą. Cel regulacji jest postawiony jasno, co precyzyjnie ujęto w technicznym streszczeniu do MSSF 8: „Przedsiębiorstwo powinno ujawniać informacje, które umożliwią odbiorcom jego sprawozdań finansowych ocenę rodzaju i wyniku finansowego poszczególnych działalności biznesowych, w jakie przedsiębiorstwo jest zaangażowane oraz identyfikację środowiska, w którym działa"33. W ramach raportowania informacji o segmentach działalności nastąpiła wyraźna zmiana podejścia. Pierwotne podejście, tj. zgodne $\mathrm{z}$ obowiązującym do końca roku 2008 MSR 14, zakładało dzielenie przedsiębiorstwa jak całości na segmenty, w konsekwencji można było przypisać do segmentów tylko niektóre kategorie ekonomiczne, natomiast podejście, które obecnie obowiązuje zgodnie z MSSF $8^{34}$ można określić, jako „składanie całości z części”. Jest to możliwe pod warunkiem, że wydzielone części jednostki będą przedmiotem rejestracji zdarzeń gospodarczych. Możliwe jest podzielenie na segmenty działalności niemal wszystkich kategorii wynikowych i bilansowych. Trudności mogą wyniknąć przy podziale takich kategorii, jak kapitał własny, aktywa inwestycyjne, środki pieniężne itp. Jednostka może zatem zdecydować, jak postąpić z takimi kategoriami; ma do wyboru dwa rozwiązania: może: nie dzielić tych kategorii i pozostawić je jako wielkości przypisane do całej jednostki (pozycje uzgadniające do wartości bilansu czy rachunku wyników przedsiębiorstwa) lub podzielić je na segmenty, stosując znane w rachunkowości narzędzie - alokację, tj. umowny klucz rozliczeniowy.

\section{Integracja rachunkowości finansowej i zarządczej w badanej spółce w latach 2001-2009}

W teorii idea integracji rachunkowości zarządczej i finansowej nie wydaje się bardzo skomplikowana, natomiast w praktyce wymaga niejednokrotnie wielu lat pracy, przekształceń, zmiany rozwiązań informatycznych oraz zmiany koncepcji sporządzania sprawozdawczości zarządczej, najlepiej obrazuje to proces integracji rachunkowości finansowej i zarządczej w latach od 2001 do 2009 w badanej spółce ${ }^{35}$. Badana spółka jest spółką zależną w ramach międzynarodowego koncernu i stanowi wyodrębniony ośrodek odpowiedzialności

${ }^{33}$ IFRS 8 Operating segments, Technical Summary, s. 1, www.iasb.org (dostęp 23.02.2007).

${ }^{34}$ MSSF 8 Segmenty operacyjne obowiązuje dla sprawozdań finansowych sporządzonych zgodnie z MSR/MSSF od 01.01.2009 r.

${ }^{35}$ Badana spółka jest częścią międzynarodowego koncernu, jako „spółka córka” międzynarodowej korporacji podlega wewnętrznym koncernowym uregulowaniom dotyczącym wszelkich procedur m.in. raportowania finansowego. Uregulowania te są ujednolicone w ramach całego koncernu. 
(centrum zysku) ${ }^{36}$. Poniżej przedstawiono schemat organizacji pojedynczej spółki jako ośrodka odpowiedzialności ${ }^{37}$ (por. rysunek 1). Autorka dla określenia najmniejszych segmentów sprawozdawczych w raportach zarządczych wprowadziła nazwę ,segmenty podstawowe” - rozumiane jako najniższy stosowany podział centrów zysków (por. rysunek 1 II poziom podziału na segmenty), który następnie jest agregowany według branż i tworzy segmenty sprawozdawcze w sprawozdaniu finansowym (por. rysunek 1 I poziom podziału na segmenty).

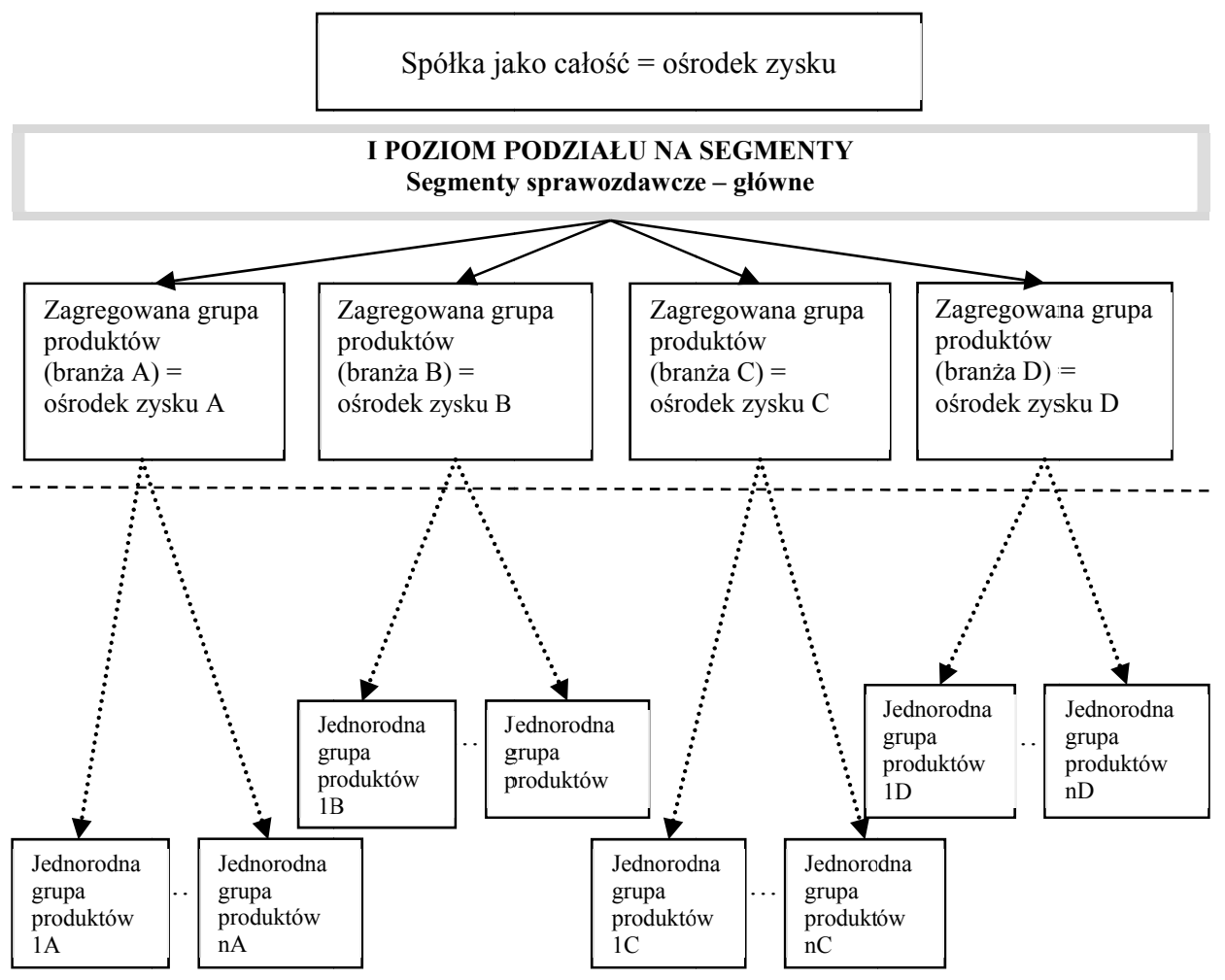

II POZIOM PODZIALU NA SEGMENTY

podzial na najmniejsze centra zysków - jedno centrum zysku to jeden typ produktów (towarów) - segmenty podstawowe

Rysunek 1. Struktura spółki - jako ośrodka odpowiedzialności Źródło: opracowanie własne.

\footnotetext{
${ }^{36}$ Można powiedzieć, że w ograniczonym zakresie jest także centrum inwestycji.

${ }^{37} \mathrm{Na}$ podstawie badanej spółki.
} 
W badanym przedsiębiorstwie sprawozdawczość dla celów zarządczych jest bardzo rozbudowana. W latach 2001-2009 ulegała znacznemu uszczegółowieniu oraz skracano terminy sporządzania poszczególnych raportów. Istnieją szczegółowe wytyczne dotyczące sporządzania raportów zarządczych. Raporty zarządcze są szczegółowe i umożliwiają bardzo wyraźne „prześwietlenie” wszelkich działań firmy, a także spojrzenie na informację finansową zagregowaną według różnych kategorii rachunku wyników. Dodatkowo pokazują najważniejsze grupy zaangażowanych $\mathrm{w}$ daną działalność biznesową aktywów i pasywów. Wartość analityczna powyższych informacji jest bardzo duża i umożliwia ocenę działań firmy $w$ różnych przekrojach oraz prowadzenie analizy w wielu przekrojach. Powyższe dane są podstawą sporządzenia raportu według segmentów zawartego w sprawozdaniu finansowym. Przy sporządzaniu sprawozdań finansowych przechodzi się z poziomu szczegółowości raportów zarządczych do poziomu wysoce zagregowanych danych.

W badanej jednostce w związku z postępującą integracją rachunkowości finansowej i zarządczej nastąpiły daleko idące zmiany dotyczące wewnętrznych procedur stosowanych $\mathrm{w}$ spółce ${ }^{38} \mathrm{w}$ zakresie wprowadzania, integrowania i agregowania danych finansowych. W spółce stosowane jest comiesięczne raportowanie na potrzeby zarządcze. Pełen pakiet raportu zarządczego składa się z rachunku wyników w wersji szczegółowej i skróconej oraz z bilansu. Wszystkie sporządzane w spółce raporty zarządcze są podzielone na ośrodki odpowiedzialności. W ramach wzoru raportu zarządczego, wraz z upływem czasu, dodawano kolejne bardziej szczegółowe pozycje (od założenia spółki w 1993 r. daje się zauważyć zwiększanie ilości informacji dostarczanej w ramach sprawozdawczości zarządczej). Ilość informacji finansowych rozrasta się także w sprawozdawczości finansowej. Zwiększanie ilości informacji finansowych dostarczanych w ramach rachunkowości finansowej i zarządczej zbiegło się w czasie ze wzrostem i rozwojem spółki ${ }^{39}$ (lata 2001-2009), który wyrażał się we wzroście obrotów ze sprzedaży oraz zwiększaniu zatrudnienia. Zmiany wewnętrzne spółki oraz światowa tendencja do zwiększania ilości ujawnień informacji finansowych spowodowały znaczny wzrost zapotrzebowania na informację finansową o wysokiej jakości, dostarczaną w coraz to krótszych terminach.

Do początku roku 2004 sprawozdania zarządcze i sprawozdania finansowe sporządzały dwa odrębne działy, następnie odpowiedzialność za obydwa typy raportów przesunięto do działu finansowo-księgowego (por. rysunek 2). Zapoczątkowano intensywne prace nad integracją rachunkowości zarządczej i finan-

${ }^{38}$ We wszystkich spółkach zależnych w ramach koncernu wprowadzono równolegle takie same zmiany.

${ }^{39}$ Oraz ze wzrostem całego koncernu także spółki dominującej. 
sowej. Celem było stworzenie jednolitej bazy dla sporządzania wszystkich raportów finansowych oraz uzyskiwanie informacji finansowej na bieżąco, takiej informacji, która spełnia wszelkie wymogi jakościowe.

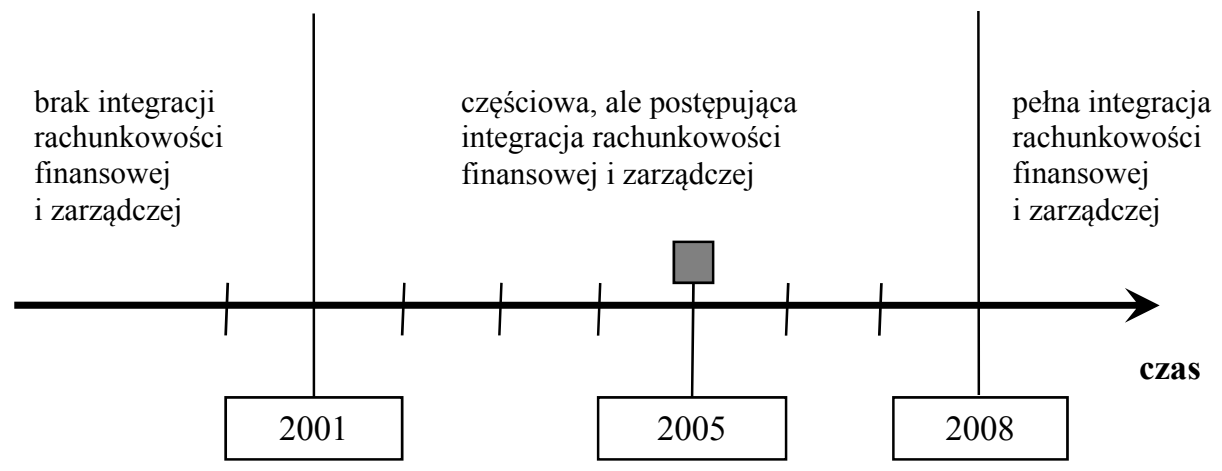

Rysunek 2. Integracja rachunkowości finansowej i zarządczej w badanej spółce Źródło: opracowanie własne.

Badana spółka do roku 2004 użytkowała szeroko stosowany w Polsce program księgowo-finansowy dla średnich przedsiębiorstw. Program ten jest dobrze dostosowany do wymogów prawa polskiego, a jednocześnie umożliwia prowadzenie analiz finansowych, jednak pozyskiwanie danych dotyczących ośrodków odpowiedzialności (centrów zysków) dla raportowania zarządczego było utrudnione i wymagało dodatkowego nakładu pracy na zagregowanie danych oraz przekształcenie ich do wymaganej przez grupę struktury raportu zarządczego. Konieczne było także stosowanie bardzo szczegółowej analityki w ramach obowiązującego planu kont. Utrudniało to codzienną pracę, a informacje finansowe nie były dostępne na bieżąco. Dużym minusem było prowadzenie oddzielnego programu komputerowego dla ewidencji zapasów, zakupów i sprzedaży. Koordynacja danych i raportowania była czasochłonna, dodatkowo powodowała niejednokrotnie dublowanie tych samych czynności w różnych działach spółki. W spółce oprócz polityki rachunkowości dotyczącej rachunkowości finansowej wprowadzono dodatkową instrukcję wewnętrzną dotyczącą raportowania zarządczego i ujęto w niej definicje poszczególnych terminów oraz przedstawiono strukturę raportowania zarządczego. Ujednolicono tym samym politykę rachunkowości w zakresie pomiaru i wyceny poszczególnych kategorii wynikowych i bilansowych, eliminując przekształcenie raportów zarządczych i ich uzgadnianie ze sprawozdaniem finansowym. Przyjęto zasady wyceny i pomiaru obowiązujące w międzynarodowych standardach, także dla raportowania zarządczego.

Nadal jednak informacja finansowa i zarządcza były traktowane niejako dwutorowo: sporządzano sprawozdania finansowe i zarządcze osobno, a następnie sprawdzano, czy poszczególne pozycje są zgodne. Grupowanie pozycji dla 
sprawozdawczości finansowej i zarządczej było odmienne. Zasady pomiaru i wyceny dla niektórych kategorii wynikowych i bilansowych były różne, a to powodowało konieczność uzgadniania, przejścia od raportów zarządczych do sprawozdań finansowych. W roku 2005 zapadła decyzja o wprowadzeniu nowego oprogramowania typu ERP II $^{40}$, które umożliwiło umieszczenie wszelkich działań biznesowych spółki w jednym systemie. Zintegrowany system połączył księgę główną, sprzedaż, zakupy, współpracę z klientami, środki trwałe, zapasy a także moduły sprawozdawczości zarządczej w całość. Ujednolicono plan kont $\mathrm{w}$ ramach koncernu, jednak nadal ani sprawozdawczość finansowa, ani zarządcza nie były generowane bezpośrednio z raportów systemu i wymagały dalszego nakładu pracy na przekształcenia danych dla wymogów sprawozdawczości według MSR/MSSF i sprawozdawczości zarządczej. Schemat raportów oraz agregacja danych dla obydwu typów raportów ${ }^{41}$ były odmienne. Uzgodnieniu podlegały ogólne grupy danych, takie jak np. sprzedaż, koszty sprzedaży, przychody operacyjne, koszty operacyjne, wynik netto, pozycje bilansowe itp.

Przełomu dokonano w 2008 r., kiedy to udało się w pełni zintegrować wymogi sprawozdawczości zarządczej i finansowej, a obydwa raporty pozyskiwane są bezpośrednio $\mathrm{z}$ systemu bez potrzeby dalszych przekształceń ${ }^{42}$. Podział danych i ich grupowanie zostały w obydwu raportach ujednolicone. Wyeliminowano tym samym błędy ludzkie przy przekształcaniu danych oraz ostatecznie różnice wyceny dla celów sprawozdawczości zarządczej i finansowej. Wprowadzono szczegółowe instrukcje dla obydwu metod raportowania, eliminując różnice w rachunkowości dla sprawozdań różnego typu - finansowych i zarząd-

40 Jak pisze A. Amanowicz: „Na przełomie lat 2000/2001 analitycy Gartner Group zredefiniowali znane od połowy lat 90. pojęcie ERP, tworząc definicje nowego standardu aplikacji do zarządzania organizacjami ERP II. Na pierwszy rzut oka przejście od ERP do ERP II wydaje się jedynie zmianą w nomenklaturze, jednakże po przyjrzeniu się ERP II w szczegółach, można łatwo przekonać się, że mamy do czynienia $\mathrm{z}$ całkowicie nową jakością $\mathrm{w}$ informatycznym wspomaganiu procesów zarządczych. Kluczowe jest $\mathrm{w}$ niej pojęcie $>\mathrm{c}$-commerce $<$, w którym litera $>\mathrm{c}<$ pochodzi od angielskiego słowa $>$ collaborative $<$, czyli współpraca. Z grubsza ujmując ERP II to zestaw aplikacji, metod zarządzania, procesów gospodarczych, technologii i usług, który ma za zadanie wspieranie procesów daleko zaawansowanej współpracy pomiędzy organizacjami gospodarczymi. Podstawowym założeniem ERP II jest otwarcie procesów gospodarczych, systemów informacyjnych i systemów informatycznych organizacji dla jej kooperantów, dostawców i klientów. Informatycznym rdzeniem ERP II pozostają nadal aplikacje do zarządzania efektywnością procesów gospodarczych organizacji, czyli standardowe pakiety ERP, jednakże rozszerzone i zintegrowane funkcjonalnie z systemami zarządzania relacjami z klientem (CRM), aplikacjami elektronicznych zakupów i sprzedaży, a także systemami zarządzania łańcuchem dostaw oraz specjalizowanymi aplikacjami finansowymi i analitycznymi Business Intelligence". A. Amanowicz, ERP II - narodziny nowego standardu, 2003, ceo.cxo.pl (dostęp 18.11.2008).

${ }^{41} \mathrm{Tj}$. sprawozdania finansowego i raportu zarządczego.

${ }^{42}$ Oprócz informacji opisowej na potrzeby sprawozdania finansowego według MSR/MSSF. 
czych. Nastąpiła pełna integracja rachunkowości zarządczej i finansowej, dane dostępne są niemal na bieżąco.

W ramach integracji rachunkowości finansowej i zarządczej przeprowadzono zmiany systemie rachunkowości finansowej, tak by dane dotyczące ośrodków odpowiedzialności potrzebne dla raportowania zarządczego mogły być dostępne bezpośrednio ze zintegrowanego systemu komputerowego. W tym celu należało ustalić raportowane segmenty (ośrodki odpowiedzialności) i nadać im odpowiednio usystematyzowaną numerację, która umożliwiła przypisanie zapisów księgowych do określonego segmentu już w momencie ich wpisywania (księgowania) w użytkowanym programie komputerowym. Podejście takie umożliwia zagregowanie zapisów $\mathrm{w}$ ramach poszczególnych centrów odpowiedzialności na podstawie danych wprowadzonych do systemu. Przypisanie do ośrodka identyfikowane jest na poziomie pojedynczej transakcji, a całość jest widziana jako suma części. Zmieniło się zatem podejście, pierwotnie wychodziło się od sprawozdań finansowych całościowych, natomiast potem zastosowano spojrzenie przez pryzmat wydzielonych ośrodków odpowiedzialności. Raportowanie zarządcze odbywa się w ściśle określonych terminach i odpowiada strukturze organizacyjnej przedsiębiorstwa ${ }^{43}$. Od początku 2005 r. szczegółowość raportów zarządczych wzrasta, następują także niewielkie zmiany struktury raportu. Do roku 2007 szczegółowe raporty zarządcze sporządzano za każdy kwartał sprawozdawczy - narastająco w ramach jednego roku obrachunkowego. Począwszy od 2008 r. po przeprowadzeniu pełnej integracji rachunkowości zarządczej i finansowej raporty sporządzane są za każdy miesiąc sprawozdawczy i mogą być analizowane osobno dla każdego miesiąca, lub narastająco za wszystkie raportowane miesiące $\mathrm{w}$ danym roku obrachunkowym. Od 2008 r., dzięki integracji rachunkowości finansowej i zarządczej, możliwe stało się znaczne skrócenie terminów raportowania. Miesięczne raporty dla kierownictwa mogą być sporządzane bardzo szybko, pierwszy raport ze sprzedaży na trzeci dzień roboczy następnego miesiąca, a całościowy raport na ósmy dzień roboczy następnego miesiąca ${ }^{44}$.

Od 2005 r. nastąpiły także zmiany dotyczące systemu rejestracji pojedynczych operacji gospodarczych, tj. ujednolicono metody wprowadzania danych do systemu księgowo-finansowego, przy ograniczeniu liczby kont rozbudowano dodatkowe wymiary, które uzyskuje dany zapis już na wejściu (por. rysunek 2). Wymiary te to w szczególności:

${ }^{43}$ Autorka dla określenia najmniejszych segmentów sprawozdawczych w raportach zarządczych wprowadziła określenie „segmenty podstawowe” - rozumiane jako najniższy stosowany podział centrów zysków, który następnie jest agregowany według branż i tworzy segmenty sprawozdawcze w sprawozdaniu finansowym.

${ }^{44}$ Według stanu na rok 2009, potem nastąpiło skrócenie raportowania zarządczego i dane dostępne są na siódmy dzień roboczy. 
1) miejsce powstawania kosztu/przychodu (cost center/profit center), tj. oznaczenie podstawowego segmentu branżowego ${ }^{45}$, do którego należy dany zapis, oznaczeniami określone są jednorodne grupy towarów/produktów (por. rysunek 1 - II poziom podziału), które potem łączone są do określonej branży (por. rysunek 2 - I poziom podziału); II poziom podziału na segmenty działalności jest podstawą dla ewidencji zapisów księgowych, natomiast podział I jest suma uzyskiwana w raportach);

2) oznaczenie czy przychód, koszt jest bezpośrednio związany z realizowaną sprzedażą;

3) przypisanie przychodów/kosztów bezpośrednich do konkretnych zamówień sprzedaży;

4) określenie czy dana sprzedaż to sprzedaż usług, towarów - wyrobów gotowych innych niż części zamienne, części zamiennych;

5) przypisanie sprzedaży do określonego typu klienta - firma powiązana kapitałowo lub niepowiązana;

6) przypisanie zapisów nie związanych bezpośrednio z konkretnym miejscem powstawania kosztu/przychodu do określonej alokacji kosztów; alokacje w systemie podzielone są na kategorie; inna kategoria stosowana jest dla kosztów personalnych, inna dla kosztów ogólnych związanych z budynkiem, energią itp., inna dla kosztów warsztatu itp.; przypisane do nich zapisy po uruchomieniu skryptu programowego są automatycznie rozdzielane na poszczególne segmenty.

Zapisy, których nie można przypisać bezpośrednio do segmentu, alokuje ${ }^{46}$ się na poszczególne segmenty według wybranego kryterium, np.:

- budynek - według procentowego udziału powierzchni zajmowanej na potrzeby każdego segmentu, podobnie jego amortyzację itp.;

- niektóre koszty pracownicze - według przyjętego procentowego udziału rzeczywistego czasu pracy danego pracownika dla każdego segmentu.

\footnotetext{
${ }^{45}$ Jednorodna grupa produktów - segment podstawowy, który łączony jest potem według kategorii branży w segment sprawozdawczy.

${ }^{46}$ E.Walińska: „Alokacja to procedura systemu rachunkowości. [...] To inaczej rozliczanie w czasie dwóch podstawowych kategorii finansowych - przychodów i kosztów. [...] Alokacje z natury rzeczy charakteryzuje uznaniowość, ponieważ podstawowym jej narzędziem jest szacunek. [...] W szerokim rozumieniu alokacja może dotyczyć zarówno pozycji bilansowych jak i wynikowych. [...]. Początkowo powstaje kategoria bilansowa (ujmowana w bilansie), która następnie jest ujmowana w rachunku zysków i strat". E. Walińska, Wartość bilansowa przedsiębiorstwa a alokacja podatku dochodowego, Wydawnictwo UŁ, Łódź 2004, s. 192-194. W niniejszym artykule pojęcie ,alokacja” pojawia się w nieco odmiennym znaczeniu, jako przypisanie danej pozycji (bez zmiany kategorii rachunku wyników czy bilansu) do poszczególnych segmentów działalności według ustalonego wewnętrznie schematu (najczęściej rozbicie procentowe). Alokowane w ten sposób mogą być pozycje bilansowe i wynikowe, nie zmienia to jednak ich miejsca w sprawozdaniu finansowym, a jedynie pokazuje zaangażowanie w poszczególne działalności przedsiębiorstwa.
} 


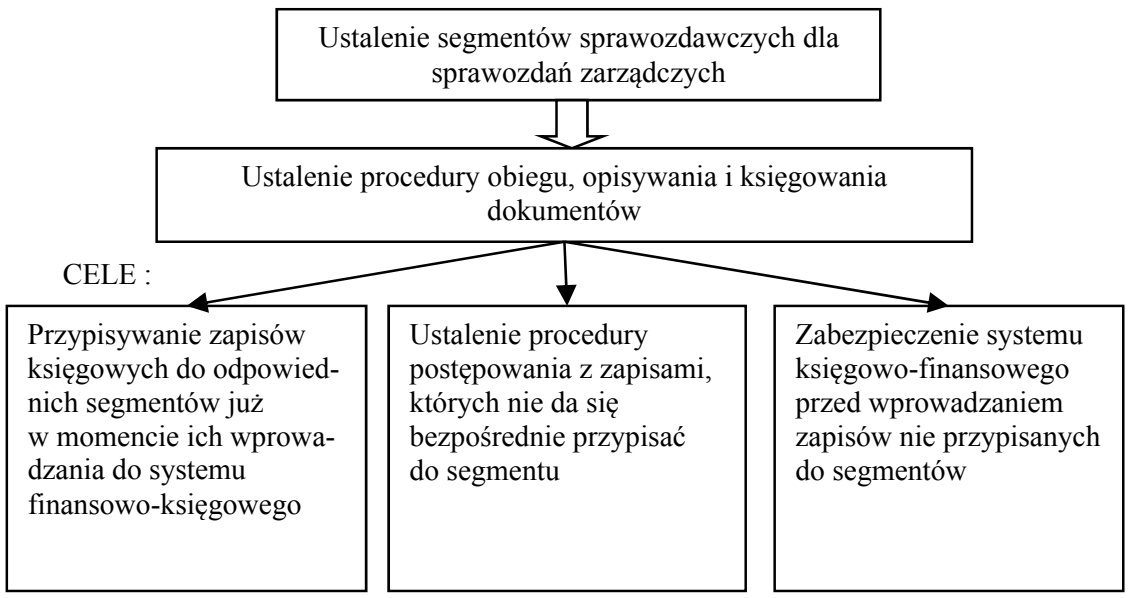

Rysunek 3. Ustalanie procedur wymaganych dla pozyskania informacji o segmentach na bazie Źródło: opracowanie własne. pojedynczych zapisów księgowych

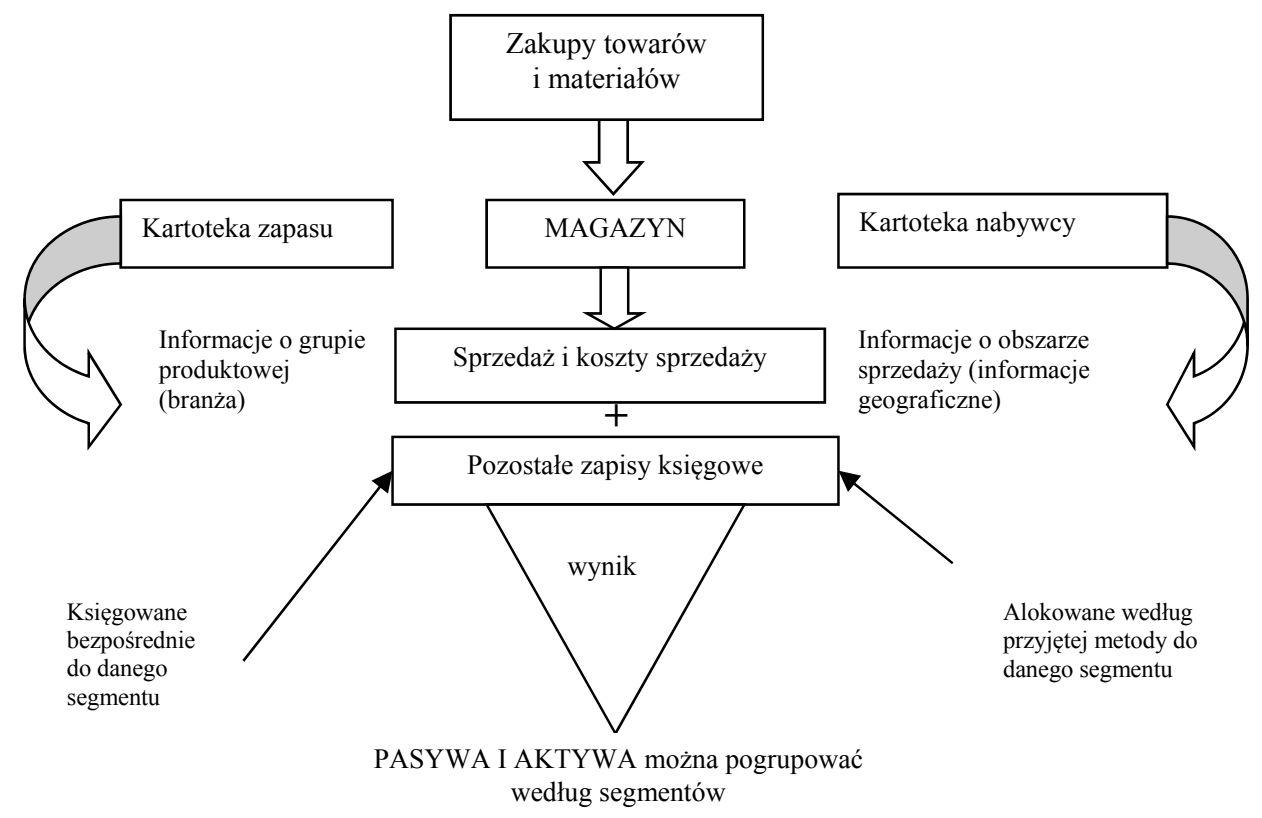

Rysunek 4. Zbieranie informacji finansowych pogrupowanych według segmentów w programie finansowo-księgowym (zintegrowany system komputerowy typu ERPII)

Źródło: opracowanie własne. 
Każda firma sama decyduje o tym, jakie są kryteria alokowania kosztów ogólnych do poszczególnych segmentów. W literaturze amerykańskiej dotyczącej zagadnienia raportowania według segmentów jako bardzo ważne podaje się ujawnianie informacji także o strukturze firmy i metodach alokacji kosztów ogólnych do poszczególnych segmentów. Zdaniem autorki informacje te są bardzo istotne dla zrozumienia raportowania według segmentów działalności i zwiększają użyteczność informacji. W praktyce potwierdza się teza, że integrowanie rachunkowości finansowej i zarządczej wydatnie zwiększa jakość i użyteczność pozyskiwanych informacji przy jednoczesnym znacznym usprawnieniu ich pozyskiwania oraz obniżeniu kosztów i eliminacji dublowanych czynności. Potwierdziły to także badania przeprowadzone w spółce.

Reasumując, w badanej spółce integrację rachunkowości finansowej i zarządczej przeprowadzono następująco:

1) wprowadzono zintegrowany system komputerowy typu ERP II, łączący w jedną całość moduł raportowania zarządczego i tradycyjny moduł finansowoksięgowy, a także inne moduły, np. sprzedaż, zapasy, zakupy itd. (informacje wprowadzone w jednym module są natychmiast widoczne w innych modułach);

2) wdrożono szczegółowe instrukcje wewnętrzne dotyczące raportowania finansowego i zarządczego (instrukcje określają definicje poszczególnych pojęć finansowych np. EBIT, zaangażowany kapitał itp.);

3) ujednolicono schemat ogólny raportowania zarządczego i finansowego, jednocześnie pozostawiając bardziej szczegółowe rozbicie centrów zysków według jednorodnych produktów ${ }^{47}$ w sprawozdawczości zarządczej; sprawozdawczość finansowa podaje kwoty ogółem, a rozbicie według segmentów sprawozdawczych dopiero w informacji dodatkowej (raportowanie o segmentach oparte jest na systemie rachunkowości zarządczej, wprowadzenie MSSF 8 nie przyniosło zmian w strukturze raportowania finansowego);

4) wprowadzono jednolity plan kont i jednolitą politykę rachunkowości $\mathrm{w}$ ramach koncernu;

5) przyjęto metody alokowania kosztów, aktywów i pasywów ogólnych do poszczególnych segmentów;

6) wprowadzono procedury bieżącej kontroli zgodności raportów zarządczych i finansowych, które uzgadnianie są co miesiąc;

7) wyeliminowano zdublowane czynności wykonywane w różnych dzia$\operatorname{lach}^{48}$.

${ }^{47}$ Por. rysunek 1. Struktura badanej spółki jako ośrodka odpowiedzialności.

${ }^{48} \mathrm{~Np}$. sprzedaż po wprowadzonych zmianach jest księgowana bezpośrednio z modułu sprzedaży przez dział zajmujący się obsługą sprzedażową, poprzednio pracownicy działu księgowego musieli drugi raz wprowadzać wystawioną fakturę do modułu finansowo-księgowego, teraz odbywa się to automatycznie. 
Dzięki powyższym działaniom zlikwidowano czasochłonne ręczne przekształcanie informacji finansowych w raporty zarządcze. Informacje zarządcze i finansowe $\mathrm{w}$ różnych przekrojach pozyskiwane są na bieżąco z systemu. Poprzez te działania ograniczono możliwości wystąpienia błędów i przekłamań w raportach sporządzanych dla celów sprawozdawczości zarządczej i finansowej. Dodatkowym bonusem było zlikwidowanie dublowania niektórych czynności przez pracowników różnych działów w spółce.

Przeprowadzone badanie spółki X wykazało, że przedsiębiorstwo stosuje rozbudowany system raportowania dla celów zarządczych oraz zaawansowane procedury dla sprawozdawczości finansowej. Z badań można wyciągnąć jednoznaczny wniosek, że raportowanie według segmentów działalności na potrzeby sprawozdawczości finansowej nie może być prowadzone bez podziału struktury przedsiębiorstwa na ośrodki odpowiedzialności - odpowiadające segmentom działalności. Rozwiązaniem uznanym za najlepsze jest osiągnięcie całkowitej zbieżności struktury raportowania zarządczego i finansowego w zakresie segmentów działalności. W badanej spółce warunek ten jest spełniony, struktura podziału jest taka sama, różni się tylko poziomem podziału danych, które dla celów zarządczych są agregowane na I i II poziomie podziału, a dla celów sprawozdawczości finansowej wystarcza I poziom szczegółowości. W sprawozdaniu skonsolidowanym dane dotyczące segmentów działalności są zebrane w jeszcze większe agregaty, nie burzy to jednak ich spójności z wewnętrznym systemem raportowania zarządczego.

W trakcie badań zidentyfikowano warunki konieczne, które powinny być spełnione dla raportowania według segmentów, czyli:

1) decentralizacja zarządzania, wyrażająca się w podziale przedsiębiorstwa na ośrodki odpowiedzialności, które odpowiadają strukturze jego działalności (jako baza dla raportowania według segmentów najlepiej sprawdza się decentralizacja - podział na centra zysków, inwestycji);

2) wdrożenie i stosowanie rachunkowości zarządczej, w tym procedur tworzenia raportowania wewnętrznego, także $\mathrm{w}$ zakresie jego prezentacji, agregacji oraz częstotliwości sporządzania;

3) raportowanie zarządcze, które powinno odzwierciedlać zdecentralizowaną strukturę przedsiębiorstwa i uzgadniać się do wartości przedstawianych w sprawozdaniach finansowych;

4) polityka i praktyka rachunkowości finansowej powinna odzwierciedlać zdecentralizowana strukturę przedsiębiorstwa; oznacza to, że informacje finansowe już w momencie wprowadzania ich do systemu finansowo-księgowego powinny być opisane i przyporządkowane do odpowiedniego segmentu działalności (dla informacji - nie dających się bezpośrednio przypisać do segmentu, ale mających wpływ na wyniki osiągane przez segment, należy ustalić procedury, które umożliwią alokowanie wartości do poszczególnych segmentów). 


\section{Zakończenie}

Reasumując, najwyższą jakość informacji finansowych dotyczących segmentów działalności osiąga się wtedy, gdy rachunkowość finansowa i zarządcza są zintegrowane i tworzą spójny system rachunkowości w przedsiębiorstwie. Współczesna rachunkowości to zintegrowana rachunkowość finansowa i zarządcza, a podstawowym problemem pozostaje nadal to, jakie informacje ma ona ujawnić zewnętrznym użytkownikom sprawozdania finansowego. Dziś rachunkowość jako spójny system jest uwarunkowana przyjętą wewnętrznie polityką oraz istniejącym w przedsiębiorstwie systemem informatycznym, umożliwiającym uzyskiwanie szczegółowych informacji i analiz ${ }^{49}$. Cele i zadania rachunkowości kształtowały się nie tylko przez praktykę gospodarczą, bardzo istotny wpływ bowiem mają $\mathrm{w}$ tym względzie różne koncepcje teoretyczne. To one są inspiracją dla rozwiązań praktyki rachunkowości z jednej strony, z drugiej zaś stoją na straży rachunkowości jako nauki. Rachunkowość finansowa tradycyjna patrzyła na sprawozdanie przedsiębiorstwa jako całość, zgodnie z zasadą podmiotowości, a rachunkowość zarządcza przeciwnie na wewnętrzną strukturę przedsiębiorstwa - najpierw pod kątem wyniku finansowego, później również od strony bilansowej. Wynikiem zbliżania obydwu podsystemów rachunkowości jest przyjmowanie przez rachunkowość finansową cech charakterystycznych dotąd dla podejścia zarządczego tj. dobrowolności, elastyczności i indywidualnego podejścia do prezentacji sprawozdań.

Zbliżanie rachunkowości finansowej i zarządczej sprzyja poprawie jakości informacji, prezentowanych $\mathrm{w}$ sprawozdaniach finansowych, może jednak obniżać przewagę konkurencyjną przedsiębiorstwa, zwiększa subiektywizm sprawozdań, ale jednocześnie umożliwia inwestorom spojrzenie na przedsiębiorstwo oczami kierownictwa. Spojrzenie takie sprzyja podejmowaniu przez inwestorów trafnych decyzji, podnosi zatem użyteczność informacji dla odbiorców zewnętrznych. Integracja rachunkowości finansowej i zarządczej oznacza korzyści nie tylko dla odbiorców zewnętrznych, ale także dla kierownictwa przedsiębiorstwa. Integracja przebiega na wszystkich istotnych ${ }^{50}$ płaszczyznach, co znacznie ogranicza rozbieżności w różnych typach raportów ${ }^{51}$ oraz skraca czas pozyskiwania raportów dla celów zarządczych. Sprawnie funkcjonujący zintegrowany system rachunkowości może dostarczać raporty dla potrzeb zarządzania niemal na bieżąco, umożliwia to kierownictwu szybkie reagowania

49 Rola systemów informatycznych w ostatnich latach zdecydowanie wzrosła programy wyłącznie księgowe zastępowane są bardziej skomplikowanymi umożliwiającymi procesowe podejście do przedsiębiorstwa na zasadzie: „wszystkie działy firmy pracują na jednym systemie”. Informacje dostępne są niemal na bieżąco i możliwe jest monitorowanie działań przedsiębiorstwa jako całości oraz szybkie reagowanie na zmieniające się warunki działania.

${ }^{50}$ Istotnych dla oceny osiąganego wyniku finansowego i sytuacji majątkowej.

${ }^{51} \mathrm{Tj}$. sprawozdaniach finansowych i raportach zarządczych. 
na pojawiające się zagrożenia ${ }^{52}$ oraz wykorzystywanie szans. W dobie dynamicznych zmian otoczenia powyższe korzyści są kluczowe dla sprawnego zarządzania przedsiębiorstwem.

\section{Literatura}

Amanowicz A., ERP II - narodziny nowego standardu, 2003, ceo.cxo.pl.

Brzezin W., Ogólna teoria rachunkowości, Wydawnictwo Politechniki Częstochowskiej, Częstochowa 1998.

Dobija M., Rachunkowość zarządcza i controlling, PWN, Warszawa 1997.

Drury C., EL-Shishini H., Research Report. Divisional Performance Measurement : An Examination of the Potential Explanatory Factors, March 2005, www2.cimaglobal.com.

Ignaszewska E., Jak wydzielić ośrodki odpowiedzialności - to nie takie proste jak się nam wydawało, „Controlling i Rachunkowość Zarządcza” 2005, nr 8, www.budżetowanie.pl.

Improving decision making in organisations, The opportunity to transform finance, September 2007, Appendix 1, www2.cimaglobal.com.

Jaruga A., Rola rachunkowości zarządczej, [w:] A.A. Jaruga, W.A. Nowak, A. Szychta, Rachunkowość zarządcza. Koncepcje i zastosowania, Społeczna Wyższa Szkoła Przedsiębiorczości i Zarządzania w Łodzi, Łódź 1999.

Jaruga A.A., Nowak W.A., Szychta A., Rachunkowość zarządcza. Koncepcje i zastosowania., Społeczna Wyższa Szkoła Przedsiębiorczości i Zarządzania w Łodzi, Łódź 2001.

Kaszuba-Perz A., Szydełko A. (red.), Rachunkowość zarządcza, Wydawnictwo Wyższej Szkoły Informatyki i Zarządzania w Rzeszowie, Rzeszów 2004.

Kiziukiewicz T. (red.), Zarzadcze aspekty rachunkowości, PWE, Warszawa 2003.

Kulpiński W., Czy controlling jest potrzebny polskiej firmie?, 2001-08-16, www.controlling.info.pl.

MSSF 8 Segmenty operacyjne, Tekst jednolity z 27.03.2010 r., Rozporządzenia Komisji (WE) nr 1126/2008 z dnia 3 listopada 2008 r. przyjmujące określone międzynarodowe standardy rachunkowości zgodnie z rozporządzeniem (WE) nr 1606/2002 Parlamentu Europejskiego i Rady, http://eur-lex.europa.eu.

Nowak E ., Zaawansowana rachunkowość zarządcza, PWE, Warszawa 2003.

Nowak E. (red.), Rachunkowość a controlling, Prace naukowe Akademii Ekonomicznej im. O. Langego we Wrocławiu, Wydawnictwo AE we Wrocławiu, Wrocław 2005.

Nowosielski S., Centra kosztów i centra zysku w przedsiębiorstwie, Wydawnictwo Akademii Ekonomicznej im. Oskara Langego we Wrocławiu, Wrocław 2001.

Nowosielski S., Controlling w zarządzaniu przedsiębiorstwem, Wydawnictwo Akademii Ekonomicznej im.Oskara Langego we Wrocławiu, Wrocław 2002.

Sierpińska M., Niedbała B., Controlling operacyjny w przedsiębiorstwie, Centra odpowiedzialności w teorii i praktyce, Wydawnictwo Naukowe PWN, 2004, www.ibuk.pl.

Sobańska I., Nowa orientacja systemu rachunkowości w praktyce polskiej w kontekście wdrażania MSR/MSSF, [w:] Cebrowska T., Kowalik A., Stępień R., Rachunkowość wczoraj, dziś i jutro, SKwP, Warszawa 2007.

Sobańska I. (red.), Rachunek kosztów i rachunkowość zarządcza, Wydawnictwo C.H. Beck, Warszawa 2003.

\footnotetext{
${ }^{52} \mathrm{~Np}$. utraty płynności.
} 
Sobańska I., Potrzeba integracji rachunkowości zarządczej i rachunkowości finansowej w praktyce jako efekt zmian zasad sporzadzania sprawozdań finansowych $w$ Polsce $i$ krajach Unii Europejskiej, „Zeszyty Teoretyczne Rachunkowości” 2004, t. 18(74), SKwP.

Sojak S., Rachunkowość zarządcza, Wydawnictwo „Dom Organizatora”, Torun 2003.

Szychta A., Etapy ewolucji i kierunki integracji metod rachunkowości zarządczej, Wydawnictwo UŁ, Łódź 2008.

Mackintosh I., The disclosure problem: setting the scene Discussion Forum - Disclosures in Financial Reporting, www.ifrs.org.

Walińska E., Wartość bilansowa przedsiębiorstwa a alokacja podatku dochodowego, Wydawnictwo UŁ, Łódź 2004.

\section{Streszczenie}

Artykuł przedstawia problem integracji rachunkowości finansowej i zarządczej, tłem dla rozważań jest raportowanie dotyczące segmentów działalności. Międzynarodowe standardy (m.in. MSSF 8 Segmenty operacyjne) wymagają przeniesienia szeregu rozwiązań stosowanych w rachunkowości zarządczej do rachunkowości finansowej i jej głównego produktu tj. sprawozdania finansowego. W artykule wykorzystano studia literaturowe oraz badania empiryczne. W praktyce integracja rachunkowości zarządczej i finansowej wymaga dużego nakładu pracy, przekształceń, zmiany stosowanych rozwiązań informatycznych oraz zmiany koncepcji sporządzania sprawozdawczości zarządczej. Oprócz tych zmian w badanej jednostce nastąpiły także daleko idące zmiany dotyczące wewnętrznych procedur $\mathrm{w}$ zakresie wprowadzania, integrowania $\mathrm{i}$ agregowania danych finansowych. Najwyższą jakość informacji finansowych prezentowanych w sprawozdaniu finansowym osiąga się wtedy, gdy rachunkowość finansowa i zarządcza są zintegrowane i tworzą spójny system rachunkowości w przedsiębiorstwie.

\section{Summary}

\section{INTEGRATION OF FINANCIAL AND MANAGEMENT ACCOUNTING, FROM THE PERSPECTIVE OF REPORTING INFORMATION ABOUT OPERATING SEGMENTS, BASED ON EMPIRICAL STUDIES}

The article presents the problem of integration of financial and management accounting, the background for discussion is the report on business segments. International standards (including IFRS 8 Operating Segments) require the transfer of a number of solutions typical for management accounting to financial accounting and its main product - financial statement. The article uses literature studies and empirical research. In practice, the integration of management and financial accounting requires a lot of work, changes in the applied procedures and IT solutions and additionally change the concept of preparing management reports. In addition to above changes in the examined entity there were also changes in its internal procedures for the entering, integration and aggregation of financial data. The highest quality of the financial information presented in the financial statement is achieved when the financial and management accounting are integrated in order to form a coherent system of accounting in the enterprise. 